\section{KULTURA i \\ POLSKA AKADEMIA NAUK \\ KOMITET SOCJOLOGII \\ INSTYTUT STUDIÓW POLITYCZNYCH \\ 2016, $\mathrm{nr} 4$}

\title{
ŻYCIE BEZ PRACY
}

Życie bez pracy jest dziś doświadczeniem znacznej części społeczeństwa polskiego. Jak pokazuje raport $W$ trosce o prace (2004, s. 66), Polska ma najgorsze wskaźniki zatrudnienia spośród wszystkich krajów Unii Europejskiej: w roku 2002 wskaźnik aktywności zawodowej wynosił w Polsce 51,5\%, gdy średnio w krajach Unii stopa pracujących wynosiła $64,5 \%$, a w krajach Europy Środkowej - 55,9\%. Składa się na to przede wszystkim najwyższe wśród krajów unijnych bezrobocie, które jesienią 2005 roku wykazywało lekką tendencję spadkową i w końcu września 2005 roku wynosiło 17,6\% ludności aktywnej zawodowo ${ }^{1}$. Gdy w 2002 roku bezrobocie w Polsce sięgało 19,9\%, odpowiedni wskaźnik dla krajów Unii Europejskiej wynosił 7,7\%, a dla krajów Europy Środkowej 14,8\% (W trosce... 2004, s. 67). Na niskie wskaźniki zatrudnienia w Polsce ma wpływ, obok wysokiego bezrobocia, obowiązujący w Polsce, jeden z najniższych, wiek emerytalny, także wysoka liczba rencistów i inne czynniki sprawiające, że znaczna część społeczeństwa utrzymuje się przede wszystkim z tzw. niezarobkowych, niezwiązanych z pracą, źródeł utrzymania. Jak stwierdziła Józefina Hrynkiewicz (2003, s. 38) na podstawie analizy wyników ostatniego spisu powszechnego, w Polsce „praca zanika jako źródło utrzymania i sposób na zmianę położenia ekonomicznego".

PierwoĐruk w: Solidarność: wydarzenie - konsekwencje - pamięć, Antoni Sułek (red.), Wydawnictwo IFiS PAN, Warszawa 2005, s. 115-136. Jest to zbiór referatów przedstawionych na konferencji pod takim samym tytułem 22-23 września 2005 r. w Warszawie.

1 „Miesięczna informacja o bezrobociu w Polsce we wrześniu 2005 roku” (www.stat.gov.pl). 
W niniejszym tekście zajmuję się „,̇yciem bez pracy” związanym z bezrobociem, czyli z wykluczeniem $z$ rynku pracy. Bezrobocie, towarzyszące ze zmienną intensywnością całemu procesowi polskich przemian w kierunku gospodarki rynkowej, to - obok ubóstwa - najważniejszy problem społeczny we współczesnej Polsce. O wadze tego problemu świadczy nie tylko jego skala: 17\%-18\% (ta bardzo wysoka stopa bezrobocia w niektórych regionach wynosi jeszcze więcej, np. w województwie warmińsko-mazurskim dochodzi do $30 \%$, a w poszczególnych powiatach osiąga nawet wyższe wskaźniki), ale i jego cechy.

Charakterystyczną cechą polskiego bezrobocia jest nadreprezentacja kobiet wśród bezrobotnych, w przeciwieństwie do innych krajów europejskich, w których problemem głównym jest brak pracy dla mężczyzn.

Kolejną cechą specyficzną polskiego bezrobocia jest brak pracy dla ludzi młodych. W przedziale wieku 15-24 lat ponad 40\%, czyli dwie piąte młodych ludzi nie ma pracy. Fakt, że wskaźnik bezrobocia młodzieży jest znacznie wyższy od stopy bezrobocia w danym kraju, nie jest polską osobliwością, lecz prawidłowością ogólniejszą. Jednak relacja stopy bezrobotnej młodzieży do stopy bezrobocia ogółem dla kraju należy w Polsce do najwyższych wśród krajów europejskich. Odsetek bezrobotnych młodych ludzi jest w Polsce ponad dwa i pół raza wyższy od ogólnego wskaźnika bezrobocia, gdy dla krajów unijnych stosunek ten wynosi średnio 1,6 (są to dane dla roku 2002) (W trosce... 2004, s. 195). Ogromny zasięg bezrobocia wśród młodych ludzi oraz nieskuteczność programów przeciwdziałających temu zjawisku to już polska specyfika. Wagi tego problemu nie sposób przecenić. Brak pracy dla młodych ludzi, dla absolwentów różnych szkół i uczelni, którzy bezskutecznie szukają zatrudnienia, ma wymiar szczególnie dramatyczny. Pojawia się bowiem w momencie startu w dorosłe, samodzielne życie, blokując plany zawodowe, osobiste i rodzinne. „Jesteśmy młodym małżeństwem - pisze 24-letnia bezrobotna autorka pamiętnika w konkursie na pamiętniki bezrobotnych z 2000 roku — nie mamy jeszcze dzieci. Ja jeszcze się uczę, muszę skończyć studia, ale co najważniejsze, oboje nie mamy poczucia stabilności, głównie finansowej i to jest bardzo ważnym czynnikiem, który blokuje, zapewne nie tylko w naszym przypadku, ale $\mathrm{i} w$ przypadku innych młodych małżeństw, powiększenie rodziny: aspekt ekonomiczny" (Pamiętniki 2005, t. 4, s. 66). Konsekwencje masowego bezrobocia młodzieży są dalekosiężne i wielowymiarowe, odnoszą się nie tylko do teraźniejszości, ale i do przyszłości, dotyczą wszystkich aspektów życia młodych ludzi, odciskają się na losach jednostek, rodzin i całego społeczeństwa. Problem jest bardzo poważny.

Inną charakterystyczną cechą polskiego bezrobocia jest tendencja do przedłużania się i utrwalania sytuacji braku pracy. Wzrasta bezrobocie długotrwałe, czyli odsetek osób pozostających bez pracy dłużej niż dwa lata; w drugim kwartale 2005 roku ponad jedna trzecia bezrobotnych $(35,8 \%)$ była bezrobotna długotrwale (GUS 2005, s. 39). W enklawach ubóstwa, zarówno wiejskich (np. w osiedlach popegeerowskich), jak i w miejskich (np. w tak dobrze przeba- 
danych łódzkich skupiskach biedy), występuje bezrobocie chroniczne, utrwalone, a nawet „dziedziczone”, „rodzinne”, czyli przekazywane następnemu pokoleniu w rodzinie (Balcerzak-Paradowska i in. 1997, s. 101; Psyk-Piotrowska 1998). Podobnie jak utrwalone ubóstwo, tak i chroniczne bezrobocie odciska się w sposób trwały nie tylko na sytuacji ekonomicznej jednostki i rodziny, na poziomie konsumpcji, ale i na jej wszystkich funkcjach: socjalizacyjnych, integracyjnych, opiekuńczych, emocjonalnych. Prowadzi do załamania się ról społecznych w rodzinie, do wewnętrznych napięć i konfliktów, tym istotniejszych, iż w warunkach bezrobocia i biedy dochodzi do pewnego zamknięcia się w kręgu rodziny, do ograniczenia dotychczasowych kontaktów ze światem zewnętrznym.

Bezrobocie jest dziś w społeczeństwie polskim jedną z głównych przyczyn ubóstwa, ale jego oddziaływanie na życie jednostek, rodzin, społeczności lokalnych i całych regionów ma wiele innych destrukcyjnych skutków. Brak pracy to także załamanie się poczucia niezależności, naruszone poczucie godności i własnej wartości, gdy brak dochodów zmusza do starań o zasiłki z pomocy społecznej, to często także pogorszenie samopoczucia i stanu zdrowia, tak psychicznego, jak i fizycznego, to utrata nadziei, stany depresyjne, myśli samobójcze. Bezrobocie i związane z tym ubóstwo są przyczyną osłabienia lub zerwania więzi społecznych oraz źródłem poczucia marginalizacji, a nawet izolacji społecznej, co przedstawię w niniejszym tekście. Zjawiska te mówią coś bardzo istotnego nie tylko o samych bezrobotnych i o ich życiu; mówią też coś ważnego o całym społeczeństwie, w tym o łączących jego członków więziach społecznych, o międzyludzkiej solidarności — lub jej braku. Tego także dotyczy niniejszy tekst.

Przygotowując wypowiedź na temat „życia bez pracy” dla celów konferencji zorganizowanej z okazji rocznicy powstania Solidarności odczuwałam pewien dyskomfort: konferencja, choć pomyślana jako naukowa, socjologiczna, zorganizowana została $\mathrm{w}$ rocznicę wielkiego wydarzenia, jakim przed 25 laty było powstanie Solidarności. Mówienie przy tej okazji o dzisiejszym bezrobociu w Polsce nie oznacza - w moim rozumieniu — przyłączenia się na przykład do byłych pracowników PGR-ów, którzy oskarżają Solidarność i jej przywódców o likwidację ich zakładów pracy, o dzisiejsze bezrobocie byłych pracowników i biedę ich rodzin i nostalgicznie wspominają pegeerowską przeszłość (zob. np. Tarkowska 2002). Jestem od tego jak najdalsza. Przyczyny bezrobocia, a także ubóstwa w Polsce, tak jak w całym świecie współczesnym, są złożone, mają charakter zarówno lokalny, jak i globalny, są pochodną zarówno dokonujących się przemian i przeprowadzanych reform, jak i skutkiem i dziedzictwem przeszłości, dawno temu podjętych decyzji, przeszłych wydarzeń i procesów ${ }^{2}$. Niezależnie jednak od przyczyn, co do których toczą się spory, samo zjawisko bezrobo-

2 Pisałam o tym wielokrotnie, analizując biedę popegeerowską, m.in. w artykule Ubóstwo $w$ bytych PGR-ach (1998) i we Wprowadzeniu do książki Zrozumieć biednego (Tarkowska 2000b). 
cia, ze względu na jego skalę i społeczne konsekwencje, zasługuje na poważną refleksję. Rocznica powstania Solidarności prowokuje wręcz do ujęcia sytuacji bezrobotnych $\mathrm{w}$ kontekście więzi między nimi a światem pozbawionym troski o pracę, skłania do refleksji nad obecnością i formami zwykłej codziennej międzyludzkiej solidarności w Polsce roku 2005, w której bieda i bezrobocie występują obok różnych postaci sukcesu, pomyślności i zaradności. Przykładem podobnego nastawienia może być wywiad, udzielony przez Kazimierza Kutza „Gazecie Wyborczej” 26 sierpnia 2005 r. i zatytułowany Nie jadę do Gdań$s k a$, podczas którego reżyser powiedział: „W Polsce «Solidarności» nie ma solidarności między ludźmi, a państwo porzuca swoich obywateli, pozwala na ich zmarginalizowanie, zapomina o nich. Ci porzuceni żyją niby w Polsce, ale w rzeczywistości gdzieś poza nią, na innym lądzie”. Mówił o dniu dzisiejszym; miał na myśli tych, którzy nie mają pracy i zmagają się z biedą, a nawet nędzą i o których państwo, w tym politycy, nie pamiętają.

Trudność druga wiąże się z tym, że konferencja odbywa się w samym środku kampanii poprzedzającej wybory do Sejmu i na urząd prezydenta. Problemy społeczne, takie jak bezrobocie czy ubóstwo, zawsze były i nadal są poddawane wartościowaniu, oceniane, a przy tym uwikłane w kontekst ideologii i polityki, i często wykorzystywane do różnych konkretnych i doraźnych celów. Tocząca się kampania wyborcza sprzyja instrumentalizacji biedy i bezrobocia, wzmacnia ideologizację i polityzację problemu, $z$ natury swej silnie nacechowanego aksjologicznie, przesłaniając dążenia do jego opisowego przedstawienia i przybliżenia. W reklamach wyborczych można oglądać twarze głodnych dzieci (pokazywane bez troski o ich godność i prywatność) i przewija się w nich nieustannie temat pracy dla bezrobotnych jako wyraz troski wszystkich bodaj partii i wszystkich kandydatów. W gorącym przedwyborczym czasie okazuje się, że każda wypowiedź, nawet referat na konferencji naukowej, bywa odbierana przede wszystkim (a może i wyłącznie) jako wypowiedź polityczna i ideologiczna. Realny problem bezrobocia i ubóstwa, dotykający jednej piątej części naszego społeczeństwa, zostaje $\mathrm{w}$ ten sposób zinstrumentalizowany, sprowadzony do roli narzędzia krytyki lub poparcia czegoś zupełnie innego. Nie jest to ani nigdy nie było moją intencją.

\section{BEZROBOCIE, UBÓSTWO, WYKLUCZENIE SPOŁECZNE}

Bezrobocie, zwłaszcza długotrwałe, jest jak najściślej związane z ubóstwem. Badania warunków życia gospodarstw domowych od wielu lat pokazują związek ubóstwa, zwłaszcza skrajnego, głębokiego, z bezrobociem, a także z takimi czynnikami jak niski poziom wykształcenia głowy rodziny, wielodzietność, zamieszkiwanie na wsi lub w małym mieście, zwłaszcza w regionach o wysokiej stopie bezrobocia (GUS 2004, s. 110). Czynnikiem decydującym o sytuacji materialnej jednostki lub jej rodziny jest miejsce zajmowane na rynku pracy. Wykluczenie $z$ rynku pracy, a także niskopłatna praca (ale to nas w tym miej- 
scu mniej interesuje) to „dwie klasyczne przyczyny ubóstwa w społeczeństwie przemysłowym” (W trosce... 2004, s. 262). Nie tylko bezrobocie pokrywa się $z$ ubóstwem, to znaczy występuje częściej w rodzinach najuboższych, w których dochody są najniższe i nie przekraczają minimum egzystencji ${ }^{3}$, ale i charakterystyka rodzin bezrobotnych jest zbieżna $z$ charakterystyką rodzin żyjących w ubóstwie: są to rodziny osób gorzej wykształconych, wielodzietne, mieszkające na wsi lub w małych miasteczkach. Zbieżność i powiązanie bezrobocia i ubóstwa pokazują wyraźnie dane statystyczne, wyniki badań sondażowych (CBOS 2005), a również materiały z badań jakościowych (Tarkowska 2000). Także Pamiętniki bezrobotnych, plon konkursu z 2000 roku, to de facto $\mathrm{w}$ bardzo wielu przypadkach pamiętniki nie tylko ludzi bezrobotnych, ale i ludzi żyjących w biedzie, a niekiedy i w nędzy.

Bezrobocie to jednak nie tylko ubóstwo, ale także wykluczenie społeczne. Stosowanie tej kategorii do rynku pracy, czyli określanie w ten sposób bezrobocia jest dziś powszechne. Zawierają ją zarówno cytowane tu raporty GUS, raport UNDP $W$ trosce o prace, dokumenty rządowe, takie jak Narodowa Strategia Integracji Społecznej dla Polski, jak i na przykład Diagnoza społeczna 2005 (Czapiński, Panek 2005, s. 246 i nast.). Konieczna jest dygresja na temat tej kategorii, powszechnie stosowanej przez badaczy ubóstwa, budzącej natomiast opór osób niebędących fachowcami i stosujących ją w wartościującym znaczeniu potocznym ${ }^{4}$. Wyjątkiem był Marcin Czerwiński, wybitny badacz kultury, który w swej ostatniej książce Pytając o cywilizacje (2000, s. 121) pisał o bezrobotnych jako „najdosłowniej wykluczonych”. Źródłem nieporozumienia jest zapewne fakt, że jest to kategoria stosunkowo nowa, dobrze zadomowiona jedynie w dyskusjach specjalistów (zob. np. Golinowska, Broda-Wysocki 2005).

Kariera terminu „wykluczenie społeczne”, „ekskluzja” to kwestia ostatnich dwu, trzech dziesięcioleci. Jest to kategoria o genezie europejskiej, kontynentalnej, w przeciwieństwie do jej anglosaskiego odpowiednika - kategorii marginesu społecznego, marginalności i marginalizacji, od dawna przyjętych w naukach społecznych. Jest nawiązaniem do klasycznej myśli francuskiej, w tym do Durkheimowskiej idei solidarności społecznej, czego wyrazem jest ścisłe powiązanie problematyki wykluczenia społecznego z kwestiami solidarności, integracji i spójności społecznej; są to niejako dwie strony tej samej monety. Kategoria ta upowszechnia się od początku lat siedemdziesiątych na forum europejskim. W kolejnych unijnych programach z zakresu polityki społecznej obserwujemy stopniowe przesuwanie się środka ciężkości z przeciwdziałania

${ }^{3}$ W czwartym kwartale 2004 roku minimum egzystencji dla gospodarstwa jednoosobowego wynosiło 377 zł, a dla gospodarstwa złożonego z rodziców i dwojga dzieci do lat $14-1018$ zł, stopa tak mierzonego ubóstwa wynosiła wówczas 12\%. Zob. Sytuacja gospodarstw domowych w 2004 roku. w świetle wyników badań budżetów gospodarstw domowych (www.stat.gov.pl/dane).

${ }_{4}^{4}$ Tak można wyjaśnić krytyczną reakcję wobec kategorii wykluczenia społecznego zastosowanej przeze mnie $w$ dyskusji nad tym referatem. Podobne niezrozumienie tej koncepcji opisuję w tekście Kategoria wykluczenia społecznego a polskie realia (Tarkowska 2005). 
ubóstwu ku zwalczaniu wykluczenia społecznego i działaniu na rzecz integracji społecznej (inkluzji, spójności). Polska, jeszcze w okresie kandydowania do Unii Europejskiej, uczestniczyła w pracach nad przygotowaniem wspólnego europejskiego memorandum w sprawie integracji społecznej. Przygotowana w 2004 roku Narodowa Strategia Integracji Spotecznej dla Polski (zob. s. 20, 23) jest najlepszym świadectwem kariery, jaką w polityce społecznej, zarówno na forum polskim, jak i europejskim, zrobiła koncepcja wykluczenia społecznego, jedna z zasadniczych - obok integracji społecznej i spójności społecznej kategorii tego programu. W myśl przyjętych w Strategii definicji operacyjnych wykluczenie społeczne jest ujmowane bardzo szeroko: „polega na niepodejmowaniu zwyczajowej i społecznie akceptowanej drogi życiowej lub wypadaniu z niej”, na „braku lub ograniczeniu możliwości uczestnictwa, wpływania i korzystania z podstawowych instytucji publicznych i rynków, które powinny być dostępne dla wszystkich, a w szczególności dla osób ubogich". Przeciwdziałanie wykluczeniu społecznemu obejmuje skutki zarówno ubóstwa, jak i bezrobocia i innych negatywnych zjawisk, rozumianych jako przyczyny lub czynniki sprzyjające wielowymiarowemu wykluczeniu społecznemu.

Wykluczenie społeczne jest ściśle powiązane $z$ ubóstwem, ale — podobnie jak marginalność i marginalizacja — z nim nietożsame; relacje między zjawiskami obejmowanymi tymi terminami zaprzątają uwagę badaczy niemal na równi z kwestiami definicyjnymi. Kategorię wykluczenia społecznego, podobnie jak koncepcje i definicje ubóstwa, charakteryzuje wielość, wieloznaczność, zmienność w czasie oraz brak jednej przyjętej definicji. W ciągu stu lat badań ubóstwa stosowane koncepcje i narzędzia badawcze podlegały istotnym zmianom w trakcie nieustannych poszukiwań ciągle nowych kategorii, coraz lepiej chwytających złożony kompleks zjawisk zwanych ubóstwem. Kategoria wykluczenia społecznego wpisuje się dobrze $\mathrm{w}$ tę ewolucję, jest bliska tendencjom do szerokiego, wielowymiarowego ujmowania ubóstwa, niesprowadzanego jedynie do czynników ekonomicznych. Jest, najkrócej mówiąc, istotnym poszerzeniem perspektywy ujmowania ubóstwa, ale nie wyczerpuje się w tej problematyce.

Jedną z zalet kategorii wykluczenia społecznego jest jej oczekiwana neutralność. Terminy takie jak bieda czy ubóstwo nie są kategoriami obojętnymi, są nacechowane aksjologicznie, w społeczeństwach nowoczesnych zyskały negatywne konotacje. Na tym tle koncepcja wykluczenia społecznego (a także marginalizacji) z założenia ma być opisowa i neutralna (kłóci się to jednak z potoczną polszczyzną, w której zarówno „margines społeczny”, jak i „wykluczenie" odbierane są jako mocno negatywnie zabarwione).

Trzeba podkreślić pewną istotną cechę kategorii wykluczenia społecznego. W odróżnieniu od niektórych koncepcji ubóstwa (tzw. behawioralnych, kulturowych, poszukujących przyczyn ubóstwa w zachowaniach i wartościach jednostek) kategoria wykluczenia społecznego przesuwa środek ciężkości w stronę wymiaru społecznego, w kierunku oddziaływania społeczeństwa, które wyklucza i marginalizuje, które się nie sprawdza w zapewnieniu jednostkom, grupom 
i zbiorowościom pełnego uczestnictwa w życiu społecznym. Kategoria wykluczenia eksponuje rolę kontekstu społecznego, pokazuje pewnego rodzaju chorobę społeczeństwa w postaci słabości więzi i braku spójności społecznej, integracji, solidarności. Stosowanie tej kategorii do zjawiska bezrobocia, zwłaszcza masowego, strukturalnego, ma głęboki sens.

W wypadku wykluczenia społecznego istotne jest, po pierwsze, z czego jednostki, rodziny, grupy lub kategorie ludzi są wykluczone, w jakiej sferze życia nie mogą uczestniczyć, dostępu do czego są pozbawione, z jakiej formy aktywności zmuszone są zrezygnować: czy dotyczy to sfery pracy, konsumpcji, kultury, oświaty, służby zdrowia, polityki, praw człowieka itd. Szczególnie ważne jest przy tym, czy jest to wykluczenie jednowymiarowe czy wielowymiarowe, skumulowane, a więc czy z jedną formą wykluczenia łączą się inne jego postaci. Po drugie, kwestią istotną jest stopień deprywacji potrzeb w danej dziedzinie, głębokość wykluczenia, które może być płytkie, częściowe, zaawansowane, skrajne. Trzecim elementem charakterystyki konkretnych postaci wykluczenia jest jego wymiar czasowy: czy ma ono charakter sytuacji przejściowej, czy też jest zjawiskiem utrwalonym, a nawet chronicznym (Kowalak 1998).

W literaturze, obcej i polskiej, wskazuje się na różne rodzaje wykluczenia społecznego, opisuje się różne kategorie ludzi wykluczonych: ubogich, bezdomnych, niepełnosprawnych, narkomanów, alkoholików, przedstawicieli mniejszości seksualnych, kobiety, dzieci, młodzież, mieszkańców wsi, mieszkańców biednych i zaniedbanych regionów (Kowalak 1998). Zastanawiając się nad obszarami wykluczenia społecznego we współczesnej Polsce, badacze wymieniają różne zjawiska, przede wszystkim — jak wcześniej wspomniałam ubóstwo i bezrobocie. Są to zjawiska mocno powiązane, choć nie tożsame. Wykluczenie $z$ rynku pracy, brak pracy, pozostawanie poza kręgiem osób zatrudnionych to jedna $z$ kluczowych i najbardziej dojmujących form wykluczenia społecznego w dzisiejszej Polsce, uruchamiająca procesy pauperyzacji i deprywacji podstawowych potrzeb bezrobotnych i ich rodzin. Jest to związane $z$ rola pracy w społeczeństwie polskim, która — zdaniem autora najpełniejszej chyba monografii socjologicznej poświęconej przemianom pracy — „jest dziś szczególnie newralgicznym obszarem życia społecznego, [...] jest to sfera, w której najsilniej krystalizują się nowe grupowe i jednostkowe interesy i która tym samym ma szansę stać się w niedalekiej przyszłości widownią nowych napięć i konfliktów społecznych" (Drozdowski 2002, s. 12-13).

\section{MIEJSCE PRACY W ŻYCIU POLAKÓW}

Sfera pracy w świecie współczesnym to obszar głębokich przemian, dokonujących się pod wpływem rewolucji informatycznej i procesów o charakterze globalnym. W sferze pracy pojawia się wiele nowych zjawisk, zagrożeń i problemów o kluczowym znaczeniu dla kształtu współczesności; piszą o tym najwybitniejsi jej badacze, by wspomnieć Ralfa Dahrendorfa, Ulricha Becka, Zygmun- 
ta Baumana czy innych. Zachodzące zmiany skłaniają badaczy do formułowania tez o końcu pracy i o przekształcaniu się społeczeństwa pracy w społeczeństwo konsumpcji. Wskazuje się na istotne przemiany charakteru pracy, w tym na jej „płynność" - zanikają wyodrębniające ją ramy czasoprzestrzenne, praca przenika i łączy się, zarówno w wymiarze czasowym, jak i przestrzennym, $z$ innymi rodzajami aktywności jednostek. Zarówno sama praca, jak i rynek pracy ulegają polaryzacji: $z$ jednej strony istnieje dobrze płatna, stabilna praca związana $z$ wysokimi kwalifikacjami, praca dla nielicznych, $z$ drugiej — praca nisko płatna, niepełna i niepewna. Jeremy Rifkin (2001, s. 13) pisał o podziale, a właściwie głębokiej polaryzacji „,...] ludności świata na dwie nieprzejednane i potencjalnie wojujące siły: nową kosmopolityczną elitę profesjonalistów, którzy kontrolują technologie i siły produkcji oraz coraz liczniejszą rzeszę bezrobotnych pozbawionych nadziei i szans zatrudnienia w nowej globalnej gospodarce zaawansowanych technologii". Rewolucja informatyczna, nowe technologie, automatyzacja prowadzą do likwidacji „tradycyjnego masowego zatrudnienia”, pozostawiając dostęp do pracy jedynie wybranym kategoriom specjalistów.

Teza o końcu pracy jest więc de facto tezą o końcu pewnego rodzaju pracy, pracy dla pewnej znacznej części społeczeństwa, o kryzysie dotychczasowych stosunków pracy, a w konsekwencji o głębokich nierównościach związanych z obecną dystrybucją pracy i o potrzebie nowego społecznego podziału pracy. Praca staje się kurczącym się lub wręcz zanikającym elementem życia społecznego nie tylko w wymiarze makrospołecznym (masowe bezrobocie), ale i w mikroskali życia ludzkiego. $Z$ różnych powodów w jednostkowych biografiach praca zajmuje coraz mniej czasu, zwiększają się natomiast obszary czasu bez pracy. Stoją za tym różne procesy wydłużające inne niż praca zajęcia i obowiązki, takie jak coraz dłuższy okres edukacji, coraz później rozpoczynana kariera zawodowa, praca intensywna, choć krótko trwająca i wiele różnych form niepełnego, elastycznego zatrudnienia. Wraz z tendencją do stopniowego obniżania wieku emerytalnego i wydłużaniem się przeciętnego czasu trwania życia ludzkiego praca zarobkowa stanowi coraz mniejszą jego część - stwierdza Ralf Dahrendorf, podkreślając, że obecnie pracujemy znacznie mniej niż pół wieku temu i że „skala tych zmian jest dramatyczna”. Szacuje, że być może praca zajmuje dziś jedynie jedną ósmą część życia przeciętnego człowieka, gdy we wcześniejszych okresach wypełniała znacznie większy fragment biografii jednostki. „Czy nadal można twierdzić — pyta Dahrendorf (1999, s. 158) że praca strukturyzuje życie jednostek, nadaje mu sens, stanowi źródło tożsamości i poczucia godności jednostek?".

Jeśli chodzi o Polskę, odpowiedź na to pytanie w znacznej mierze będzie twierdząca. Choć badacze znajdują w naszym społeczeństwie pewne symptomy „społeczeństwa konsumpcji”, nadal jest ono pod wieloma względami „społeczeństwem pracy" (zob. Tarkowska 2004), czyli społeczeństwem, w którym życie jego członków reguluje przede wszystkim praca zarobkowa, w którym praca nadal jest swoistym „biletem wstępu” - by odwołać się do znanego 
zwrotu Dahrendorfa (1993, s. 227) — do wielu zasobów i wielu możliwości, a jej brak oznacza ich blokadę, czyli de facto wykluczenie $z$ możliwości zaspokojenia wielu potrzeb różnej natury: ekonomicznych, społecznych, kulturowych, psychicznych.

Wspomniane na wstępie tego tekstu charakterystyczne cechy obecnego bezrobocia w Polsce (bardzo wysoka stopa bezrobocia w ogóle, a w szczególności wśród młodych ludzi, zjawisko bezrobocia długotrwałego, chronicznego, a nawet - w pewnych środowiskach i rodzinach - swoiście „dziedziczonego”, ścisły związek bezrobocia z ubóstwem i inne) sprawiają, że wokół pracy (i jej braku) koncentrują się emocje, oczekiwania, nadzieje i obawy zarówno bezrobotnych, jak i tych, którzy mają zatrudnienie. Zdaniem Małgorzaty Sikorskiej (2002, s. 23): „W ciągu 10 lat praca stała się dla Polaków jednym z najistotniejszych aspektów życia”. Co więcej, autorka ta stwierdziła zjawisko „przeceniania” pracy w społeczeństwie polskim, co polega na tym, że „praca jest obecnie postrzegana jako coś, co nie tylko zaspokaja wszelkie potrzeby jednostki (zarówno materialne i samorealizacyjne, jak bezpieczeństwa i przynależności do grupy), lecz stanowi także punkt skupienia wszystkich elementów, z których budowana jest jej tożsamość" (Sikorska 2002, s. 39).

Brak pracy - jej utrata lub niemożność znalezienia zatrudnienia przez młodych ludzi wchodzących w dorosłe życie - urasta w tej sytuacji do roli wielowymiarowego dramatu. Utrata pracy jest $\mathrm{w}$ pierwszej kolejności utratą środków do życia, wejściem na drogę zubożenia, wegetacji i codziennej walki o przetrwanie. Jest naruszeniem poczucia elementarnego bezpieczeństwa, źródłem niepewności i nieprzewidywalności dotyczącej wielu bądź wszystkich aspektów życia. Jest przyczyną osłabienia lub zerwania dotychczasowych kontaktów społecznych; jest głębokim naruszeniem poczucia tożsamości we wszystkich wymiarach i rolach: zawodowych, rodzinnych, towarzyskich, społecznych. Brak pracy to załamanie się poczucia godności, własnej wartości, przydatności zawodowej i społecznej, to także źródło zachwiania równowagi psychicznej, przyczyna depresji, wielu innych chorób, nadużywania alkoholu, myśli samobójczych. Generalnie rzecz ujmując, brak pracy jest podłożem wykluczenia i samowykluczenia $z$ wielu dotychczasowych form aktywności i w wielu wymiarach. Zjawiska te dobrze pokazują pamiętniki bezrobotnych.

\section{ŻYCIE BEZ PRACY W PAMIĘTNIKACH BEZROBOTNYCH}

Pamiętniki bezrobotnych, których pierwsze cztery tomy zostały opublikowane w latach 2003-2005, to plon konkursu zorganizowanego w 2000 roku przez Instytut Gospodarstwa Społecznego Szkoły Głównej Handlowej w Warszawie w nawiązaniu do słynnego konkursu i do słynnych Pamiętników bezrobotnych, zebranych na przełomie 1931-1932 roku przez IGS pod kierunkiem Ludwika Krzywickiego i wydanych w 1933 roku. Pamiętniki z lat trzydziestych, będące głosem „zrozpaczonych, zdenerwowanych i rozżalonych”, jak je określił 
Krzywicki, odsłoniły dramatyczny fragment rzeczywistości społecznej czasów Wielkiego Kryzysu, wówczas niedostatecznie znany i zbadany. Ich publikacja stała się ważnym wydarzeniem społecznym i literackim, czego wyrazem blisko 250 recenzji, omówień i komentarzy, jakie ukazały się wówczas na łamach prasy krajowej i zagranicznej ${ }^{5}$.

Pamiętniki bezrobotnych dziś publikowane nie doczekały się takiego rozgłosu, nie spotkały się z odbiorem porównywalnym do tego, jaki miał miejsce w latach trzydziestych. Weszły głównie do obiegu specjalistycznego jako cenne uzupełnienie nieporównywalnie bogatszej dziś wiedzy na temat bezrobocia i jego różnych aspektów, są analizowane przez badaczy, rzadziej przyciągają uwagę mediów i opinii publicznej ${ }^{6}$.

A tymczasem pewne charakterystyczne cechy dokumentów osobistych, relacji autobiograficznych, które tak uderzyły czytelników pamiętników sprzed siedemdziesięciu lat, dziś również zasługują na uwagę. Mam na myśli bezpośredni, osobisty, subiektywny, emocjonalny wymiar doświadczenia bezrobocia. Problematyka ta stała się obszarem dociekań już na podstawie pamiętników $z$ lat trzydziestych. Bohdan Zawadzki i Paul Lazarsfeld dostrzegli w tych materiałach "psychiczną historię bezrobotnego" i poddali je wnikliwej analizie z perspektywy psychologicznej. Ich artykuł z 1935 roku The psychological consequences of unemployment ${ }^{7}$ był analizą Pamiętników bezrobotnych $\mathrm{z}$ perspektywy jednostkowego, psychologicznego wymiaru doświadczeń bezrobotnych, czyli różnych emocjonalnych faz reakcji na sytuację utraty i braku pracy, oraz propozycją typologii postaw wobec tej sytuacji: aktywności, rezygnacji, załamania, apatii, poczucia degradacji i marginalizacji, agresji skierowanej przeciw sobie (myśli samobójcze), najbliższej rodzinie (plany pozbawienia życia najbliższych) i społeczeństwu (ostra krytyka, groźby). Ten wymiar relacji pamiętnikarskich bezrobotnych - świadectwo emocji i krańcowych stanów psychicznych — okazał się tak istotny w świetle później zgromadzonej wiedzy psychologicznej i socjologicznej na temat bezrobocia, że wpływ utraty pracy na stan psychiczny jednostek został wyodrębniony w odezwie konkursu IGS z 2000 roku jako ważny i wart uwagi problem. Trzeba jednak pamiętać, że niezależnie od tej bezpośredniej wskazówki, osobista, w tym emocjonalna, interpretacja doświadczeń jest immanentną cechą każdej relacji autobiograficznej i wielką wartością tego rodzaju materiałów.

Bezrobocie ma wiele postaci i przybiera wiele form w zależności od wielu czynników: wieku, płci, wykształcenia, sytuacji rodzinnej bezrobotnego, sposobu utraty pracy, jej charakteru, czynników osobowościowych i innych. Być

${ }^{5}$ Zostały opublikowane w powojennej reedycji Pamiętników bezrobotnych (1967), w części pt. „Pamiętniki w świetle prasy”.

${ }^{6}$ Przykładem świetnego medialnego wykorzystania Pamiętników bezrobotnych może być artykuł Barbary Pietkiewicz Siostry niszczycielki („Polityka”, 14 stycznia 2006).

7 Przekład polski pt. Psychologiczne konsekwencje bezrobocia (1993). 
bezrobotnym - znaczy wiele różnych sytuacji i doświadczeń. Czym innym jest dla człowieka, który niedawno utracił pracę, czym innym dla kogoś, kto od kilku już lat żyje bez pracy, czym innym dla osób młodych, które jeszcze nie rozpoczęły swej drogi zawodowej i nie mogą na nią wejść z powodu braku pracy, czym innym dla osób w wieku średnim czy przedemerytalnym, które okazują się nagle zupełnie niepotrzebne i nieprzydatne na rynku pracy. Czym innym jest brak pracy dla osoby niemającej rodziny, czym innym dla samotnej matki, której żaden pracodawca nie chce zatrudnić ze względu na małe, wymagające opieki dzieci, czym innym dla jedynego żywiciela licznej, wielodzietnej rodziny. Wszystkie te sytuacje $\mathrm{w}$ perspektywie indywidualnego doświadczenia biograficznego ukazują swoisty dramatyzm. Pamiętniki bezrobotnych to bardzo zróżnicowane wersje losów ludzi bez pracy; łączy je wspólny, podobny sposób przeżywania tego doświadczenia.

Bardzo trudnym doświadczeniem jest życie poniżej minimum egzystencji, gdy liczy się nie tylko każda złotówka, ale dosłownie każdy grosz, jak w życiu samotnego mężczyzny, $z$ trudem utrzymującego się na powierzchni: „w portfelu 1,90, chleb za 1,10...” (t. 2, s. 163) ${ }^{8}$; „mam 10 groszy w portfelu, nie wiem, za co kupić chleb” (t. 2, s. 153). Inny: „na mszę dałem jeden grosz. Więcej mnie nie stać" (t. 3, s. 156). Ale trudnym doświadczeniem jest nie tylko bieda i codzienna walka o zdobycie kilku groszy, ale także życie „na garnuszku” u rodziców - przypadek małżeństwa absolwentów nauk politycznych, którzy wraz z małym synkiem są utrzymywani przez rodziców. „Moi rodzice nie są bogaci — pisze młody człowiek. - Gdyby nie ich łaska, czy też rodzicielska miłość, byłoby tragicznie" (t. 4, s. 94). Relacje bezrobotnych, którzy wzięli udział w konkursie z roku 2000, to obszerne materiały dokumentujące różne aspekty życia bez pracy, w tym w biedzie. Śmiało można by je nazwać „pamiętnikami ludzi biednych”. Są zapisem trudnej egzystencji, w której pojawia się niedożywienie, spożywanie małowartościowych produktów, zdarza się też głód. „Z głodu zaczynają mi się mylić dni tygodnia" - pisze samotny mężczyzna, zwolniony $z$ pracy $w$ ramach redukcji i nie mogący znaleźć nowej, który przez szereg dni wydawał na jedzenie po 3 zł 66 gr dziennie (t. 3, s. 173). Pamiętnikarze odnotowują, ile schudli na wymuszonej diecie i jak niekorzystnie wyglądają, co może być istotne $\mathrm{w}$ ich poszukiwaniach pracy. Opisują zagrożenia zdrowotne, choroby, których nie ma jak leczyć, bo brak pieniędzy na wizyty u specjalistów i na leki. Pieniędzy brakuje na podstawowe opłaty, czemu towarzyszy ciągły lęk przed eksmisją, komornikiem, a także listonoszem, który „z biegiem czasu staje się posłańcem złych wiadomości i przynosi do domu tylko złe listy" (t. 4, s. 90). W pamiętnikach znajdujemy szczegółowe opisy gospodarowania ograniczonymi środkami, szczegółowe opisy zakupów spożywczych (margaryna, smalec, chleb, ziemniaki, cebula, korpusy kurze), zapasów żywności (np. margaryna,

${ }^{8} \mathrm{~W}$ nawiasie podaję numer tomu i stronę Pamiętników bezrobotnych (2005). 
smalec, jedna łyżeczka kawy zbożowej, dwie łyżeczki herbaty, t. 2, s. 142), przygotowywanych i spożywanych potraw. Jak stwierdza Anna Zawadzka (2005, s. 37) w porównawczej analizie pamiętników bezrobotnych $z$ lat trzydziestych i obecnych: „Wszyscy piszący poświęcają ogromną część pamiętników na szczegółowe informacje o jedzeniu: co jedzą, za ile, skąd udało się jedzenie zdobyć, gdzie je kupili, czego nie kupili, co planują ugotować jutro, jakie posiłki dają dzieciom itd." Równie szczegółowe są opisy źródeł i wysokości dochodów, a z drugiej strony - wyliczenia i sumy comiesięcznych płatności, rosnących długów do zapłacenia i rozmaitych zaległości. Powtarza się te obliczenia, jakby oczekując za każdym razem na bardziej pomyślny ich wynik. Także poszukiwania pracy opisywane są ze wszystkimi detalami: ile i do kogo wysłano CV, ile pieczątek wymaganych przez Urząd Pracy jako dowód poszukiwań pracy udało się zdobyć i w jakich zakładach pracy, do kogo i ile wykonano telefonów w sprawie pracy, na ilu rozmowach w sprawie pracy się było, ilu pracodawców nie odpowiedziało na oferty itd. Widać, jakie sprawy są główną troską bezrobotnych i co wypełnia ich życie. Nie są to czynności przyjemne, poszukiwania pracy są zajęciem czasochłonnym, męczącym i upokarzającym, ich wyliczeniu towarzyszy opis emocji - rozczarowania i rezygnacji po kolejnej odmowie w sprawie pracy: „Byłem całkowicie zrezygnowany, załamany psychicznie. Ręce kolejny raz mi opadły" (t. 3, s. 177). I radość ze zdobycia każdej pracy - doraźnej, interwencyjnej, także pracy na czarno. Każda uzyskana praca odnotowywana jest jako sukces, a nawet szczęście: „Byłam szczęśliwa, znów miałam cel w życiu. Pełna nadziei i ufna, że będzie to moja stała praca, codziennie rano umalowana, zadbana pędziłam do pracy. Tam czułam się potrzebna, tam zapominałam o swych domowych kłopotach i o wszystkim, co mnie dręczyło. Praca oraz kontakt $\mathrm{z}$ ludźmi przywracały mi wiarę w siebie i pozwalały odkrywać siebie na nowo. Utwierdzały mnie, że się do tej pracy nadaję i że jestem jeszcze coś warta" - wypowiedź kobiety 48-letniej, od kilku lat bez pracy (t. 4, s. 90-91). Lektura pamiętników pokazuje ważną rolę, jaką nawet dorywcze, okazyjne, czasowe, na umowę lub bez umowy (i na ogół w szarej strefie) zatrudnienie pełni nie tylko $\mathrm{w}$ zaspokajaniu potrzeb materialnych życia codziennego, ale i dla samopoczucia jednostek i ich społecznego funkcjonowania. Prawie każdy pamiętnik bezrobotnego zawiera uwagi i przemyślenia na temat pracy: „A przecież potrzeba nam do szczęścia tylko PRACY!” (t. 2, s. 236). „Coraz częściej rozmyślam nad sensem życia. Wiem, że praca jest wartością, może najważniejszą, w życiu każdego z nas” (t. 2, s. 17). „Praca to nasza pozycja społeczna, czujemy się silniejsi i szczęśliwsi, i bezpieczni, przyszłość nie budzi w nas obaw" - 40-letnia kobieta $z$ byłego PGR-u (t. 3, s. 78). Potrzeba pracy przybiera nieraz charakter rozpaczliwego wołania, wręcz modlitwy o pracę: „Boże mój kochany — dopomóż. Serce mi wali, ściska coś w gardle. Żyć się już nie chce. Panie mój spraw, abym był natchniony lepszym umysłem, abym mógł znaleźć pracę, Jezu kochany uczyń dla mnie tę łaskę i daj mi ją, abym mógł Ciebie chwalić do końca moich dni" - mężczyzna 48-letni, samotny, bez środków do życia (t. 3, s. 169). 
Pamiętniki to własna historia bezrobocia autorów: dzieje ich pracy, opis tego, jak ją po raz pierwszy stracili, jak to przeżywali, jak sobie radzili z tą sytuacją, jak poszukiwali pracy, jak ją znajdowali i znów tracili. Liczne porażki i kolejno ponawiane próby rozpoczynania wszystkiego od nowa. Wyzysk przez nieuczciwych przedsiębiorców, zetknięcie się z bezdusznością instytucji. W niektórych wypadkach historia bezrobocia to tak naprawdę historia intensywnej, często zmienianej, dorywczej, na ogół nierejestrowanej pracy w szarej strefie, przynoszącej okresowo nawet liczące się dochody. Na ogół jednak praca na czarno pozwala po prostu przeżyć, wspomagając niedostateczne dochody lub jako jedyny dochód. Ma ponadto ogromną wartość psychiczną, odbudowuje wiarę w siebie i poczucie godności.

Życie bez pracy jest trudne, niepewne i niestabilne. Wypadek losowy, na przykład wypadek samochodowy czy choroba, prowadzi wprost do katastrofy ekonomicznej rodziny. Jest to także życie smutne, szare, pozbawione radości, przyjemności i rozrywki. „Troska o jutro - oto nasza rozrywka” — pisze sarkastycznie bezrobotny absolwent studiów uniwersyteckich (t. 4, s. 101). Kino i teatr są poza zasięgiem możliwości finansowych, główną rozrywką i ucieczką od trosk życia codziennego pozostaje telewizja, niekiedy także książki, które zdaniem owego młodego człowieka, czytelnika książek historycznych, „są chyba raczej formą ucieczki przed szarą rzeczywistością niż rozrywką" (t. 4, s. 100).

Telewizja czy radio są również źródłem stresu, ze względu na kontrast rzeczywistości mediów z rzeczywistością ich życia, kontrast uderzający zwłaszcza w okresach świąt. „W Wigilię słuchając radia odczuwałem to jak sadystyczne znęcanie się nad moim podniebieniem, kiedy znane osoby podawały przepisy na potrawy wigilijne, poza śliną łaknienia przeliczałem, ile dni bym przeżył za jedną potrawę wigilijną” (t. 2, s. 147). „Święta to dla mnie najgorszy czas. Wszystkich ogarnia szał zakupów, kuszą reklamy w telewizji. Wszyscy biedni ludzie przeżywają potworny stres” (t. 2, s. 201). „W telewizji pokazują bogato zastawione stoły, a ja siedzę ubrana w kilka swetrów i tylko patrzę" (t. 2, s. 300). W takich momentach szczególnie wyraźnie pojawia się towarzyszące bezrobotnym poczucie osamotnienia, wręcz wykluczenia, oraz dotkliwa świadomość bycia kimś zbędnym, niepotrzebnym. Bezrobotny czuje się wykluczony: „Co się czuje, gdy się zostaje bezrobotnym? Pierwsze uczucie to świadomość swojej nieprzydatności w społeczeństwie" - 54-letni były pracownik PGR-u (t. 3, s. 94). „Czuję się zbędnym śmieciem w naszym kraju, bezwartościowym typem. Zawsze starałam się być prawym człowiekiem” - 40-letnia bezrobotna z byłego PGR-u (t. 3, s. 76). „Nie opuszcza mnie zniechęcenie. Czuję się pusta, zmęczona. Takie nic, margines społeczny. Nikomu niepotrzebna" - 49-letnia kobieta $z$ wyższym wykształceniem, matka dwojga dorastających dzieci (t. 1, s. 77). Ktoś inny pisze o bezrobociu jako o „lawinowej produkcji ludzi niepotrzebnych" (t. 1, s. 176). Towarzyszy temu przekonanie, wyrażane prawie w każdym pamiętniku, że praca jest tylko dla wybranych, dla „swoich”, że bez układów i dojść uzyskanie pracy jest niemożliwe. „Inna jeszcze uwaga 
nasunęła mi się w trakcie moich poszukiwań pracy. Bez znajomości i protekcji zwykły człowiek nie ma czego szukać! Dobre miejsca pracy są zarezerwowane tylko dla rodzin i znajomych «ludzi na stołkach». Dostęp innych osób jest wręcz niemożliwy" (t. 3, s. 85).

Otaczająca rzeczywistość w ujęciu bezrobotnych dzieli się na dwa odrębne, niepowiązane ze sobą światy. Utrata pracy znaczy utratę dotychczasowego środowiska i przejście do gorszego świata - świata biedy, zerwanych kontaktów międzyludzkich, samotności. Jak napisał jeden z bezrobotnych: „Zacząłem zauważać nagle, jak bardzo zaczął zmieniać się stosunek przyjaciół, znajomych i sąsiadów wreszcie, do mnie i mojej rodziny. Z przyjaciółmi poszło najszybciej. Naprawdę, niewiele czasu trwało odsunięcie się od nas wszystkich, kiedy tylko zaczęło nam wieść się gorzej” (t. 1, s. 171). Podobnie inny: „Obecnie zanikła sąsiedzka solidarność. Piszę to z własnego doświadczenia [...]. Zapraszano nas, byliśmy lubiani, weseli, tzw. "dusze towarzystwa», ale teraz, gdy jesteśmy bez środków do życia, to i znajomi o nas zapomnieli [...]. Nie masz kasy, jesteś nikim. I nie liczą się lata znajomości, wspólnie spędzone wakacje itp." (t. 2, s. 13-14).

Bezrobotnym towarzyszy poczucie osamotnienia, a nawet izolacji społecznej. "Ja czuję to, to odsuwanie się społeczeństwa od nas, od ludzi biednych, którzy nie potrafią odnaleźć się w nowej sytuacji, są spychani na margines" 40-letnia bezrobotna matka trojga dzieci (t. 2, s. 213). „Dostaliśmy od kuzynki zaproszenie na wesele. Niestety, ale byliśmy zmuszeni odmówić. Wiadomo $z$ jakich względów [...]. Niedługo zerwiemy wszelkie więzi rodzinne. Zostaniemy sami na tonącym okręcie" (t. 2, s. 217). Z czasem to sami bezrobotni zaczynają unikać innych: „Z każdym dniem rośnie we mnie niechęć do kontaktów z innymi. Świadomie wybieram izolację i sprawia mi to ulgę. Nawet myśl o powrocie do społeczności jest przykra" - samotna 46-letnia kobieta z niepełnym wyższym wykształceniem (t. 2, s. 249). „Muszę być sama. Coraz trudniej żyć między ludźmi. Coś się znów wyczerpuje i wygasa, aż w końcu nic chyba we mnie nie zostanie. Żadnych uczuć, pustka, koniec” (t. 2, s. 223). Im dłużej trwa życie bez pracy, tym izolacja się pogłębia: „Za kilka dni minie siedem miesięcy, od kiedy siedzę w swoim mieszkaniu jak w więzieniu. Nawet skazani wychodzą częściej na przepustki niż ja. Po kilka dni z nikim się nie widuję, ani też z nimi nie rozmawiam. Nawet przez telefon" (t. 2, s. 277). Interpretacja tej sytuacji jest prosta: „Biednych się nie lubi. Bieda jest taka nieestetyczna, prawie śmierdzi" (t. 2, s. 250).

Najkrótsze podsumowanie tego fragmentu: bezrobocie to nie tylko bieda, brak środków, ale i podążające w ślad za tym wielowymiarowe wykluczenie społeczne i pełna, precyzyjna świadomość tego stanu u samych bezrobotnych.

Biografie bezrobotnych to zapis walki o przeżycie, rozpaczliwych poszukiwań pracy i środków do życia, upokarzających starań o zasiłki i pożyczki, czasochłonnych strategii oszczędnościowych. To jednocześnie zapis ich stanów emocjonalnych, poczucia degradacji, bezradności, rezygnacji, apatii, frustra- 
cji, lęków i obaw. Nastroje depresyjne, poczucie sytuacji bez wyjścia i myśli o śmierci pojawiają się niemal w każdym pamiętniku. „Nie byłam wolna od myśli samobójczych... Bezradność, rozpacz, apatia, brak wizji na przyszłość" — kobieta z wyższym wykształceniem, matka dwojga dzieci (t. 1, s. 82). „Coraz częściej w dzień leżę i bezmyślnie gapię się w sufit. To nie jest życie. Każdy dzień jest walką o przetrwanie. Żyjesz w ciągłym strachu, obawie, sam nie wiesz, przed czym, ale się boisz. Boisz się ludzi, przebywania wśród nich. Czujesz się zaszczuty" - bezrobotny ślusarz, ojciec dwojga dzieci (t. 2, s. 12-13). „Nie spałem całymi nocami” - bezrobotny ojciec sześciorga dzieci (t. 1, s. 51). „Trwamy w beznadziei, bez szans na zmianę losu na lepsze” — mężczyzna 47-letni, ojciec nastoletniej córki (t. 1, s. 175). Źródłem niepokoju, stresu i obaw jest przyszłość. „Najgorszy jest brak perspektyw na lepsze jutro” (t. 2, s. 249). „Z miesiąca na miesiąc jest coraz gorzej, lękam się o naszą przyszłość” (t. 2, s. 193). „Żyje się z dnia na dzień, już nawet nie myśląc o przyszłości — bo i o jakiej? Pozostaje tylko nadzieja i często powtarzane stwierdzenie, że musi być lepiej, bo już gorzej być nie może" (t. 1, s. 282). Obawy budzi przede wszystkim przyszłość dzieci. Myśl o dzieciach z kolei powstrzymuje zamiary samobójcze.

Życie bezrobotnego to codzienna walka ze sobą, ze złym samopoczuciem, apatią, depresją. „Codzienna walka ze wstawaniem. Brak wizji działania” bezrobotna kobieta $z$ wyższym wykształceniem, matka dwojga dzieci (t. 1, s. 73). „Nie wychodzę z domu. Leżę całymi godzinami i myślę o tym, co było, co będzie. Dlaczego to na mnie trafiło? Chwile zwątpienia są tak silne, że jest mi wszystko jedno. Nie zależy mi nawet na życiu" - bezrobotny ojciec dwojga dzieci (t. 2, s. 18-19). Ten sam pamiętnikarz ciągle o tym samym: „Bieda nie boli. Zawija się człowiek w kokon beznadziei i czeka na lepsze czasy. Tkwi tak długo, jak mu sił wystarczy. Resztki uwagi skupiają się na tym, by przeżyć w biedzie” (t. 2, s. 24). „Boże, nie dopuść do tego, aby nadzieja we mnie całkiem wygasła, a pozostała tylko bezsilność i cierpienie" - 40-letnia matka trojga dzieci (t. 2, s. 224).

Cytowane tu fragmenty pamiętników nie oddają całego dramatyzmu życia bez pracy i wszystkich skutków tego niszczącego doświadczenia. Zmusza ono do przewartościowania całego dotychczasowego życia, zmienia w sposób radykalny stosunek do rzeczywistości i hierarchię wartości. Oto jak podsumowuje doświadczenie braku pracy młody absolwent nauk politycznych, bezrobotny od chwili ukończenia studiów, utrzymywany — wraz z żoną i małym synkiem — przez rodziców: „Mam nadzieję, że udało mi się ukazać, jakie spustoszenie w człowieku i ludzkiej godności czyni brak pracy. Bezrobocie wyleczyło mnie z optymizmu i romantyzmu. Wpłynęło na zmianę mych idei i naczelnych wartości. Z człowieka młodego, wesołego i śmiało patrzącego w przyszłość stałem się pesymistycznym i zgorzkniałym starcem. Od życia nie oczekuję niczego dobrego. Przyzwyczaiłem się do porażek, niedostatku i zmartwień. Nie mam jeszcze 26 lat, a już kilka srebrnych nici na skroniach. Nic to" (t. 4, s. 107). 
Krańcowy pesymizm przenika ogólną refleksję nad własnym życiem 48-letniej kobiety, od 10 lat bez stałej pracy, matki trojga dorosłych już dzieci: „Za 12 lat osiągnę wiek emerytalny. Co mnie czeka? Jaka emerytura i jaka starość? Jeśli teraz nie wywalczę swego i nie zdołam znaleźć stałej pracy, to po co mam w ogóle dalej żyć? Bez pracy, bez domu, bez pieniędzy, bez sensu dalszego życia. Myśli samobójcze powrócą jak bumerang i tylko nie wiem, co wtedy będzie silniejsze, rozsądek czy brak rozsądku? Brak tej jednej jedynej iskierki nadziei i czegoś lub kogoś, kto by mnie powstrzymał. Czy wystarczy mi sił, by to wszystko znieść? Nie wiem. Jedyną życzliwą i najukochańszą duszą, jaka przy mnie tkwi, jest mój również utrapiony mąż. Jak te dwie sieroty żyjemy i idziemy przez to podłe nasze życie razem, zmagając się ze wszystkimi przeciwnościami losu" (t. 4, s. 91). Nie wiadomo, komu bardziej współczuć: młodemu człowiekowi, który na starcie dorosłego życia napotkał bariery nie do pokonania, czy kobiecie w średnim wieku, która niczego dobrego już od życia nie oczekuje.

\section{ZAKOŃCZENIE: W STRONĘ SOCJOLOGII WSPÓŁODCZUWAJĄCEJ}

Bezrobocie jest zjawiskiem wielowymiarowym i zróżnicowanym, uwarunkowanym wieloma czynnikami różnej natury. W niniejszym tekście skupiłam się na pewnej tylko warstwie życia bez pracy, na subiektywnym, emocjonalnym wymiarze wykluczenia $z$ rynku pracy i w konsekwencji z życia społecznego. Brak pracy, utrata pracy, przedłużający się stan bezrobocia to zjawiska wywołujące nasilenie różnego rodzaju emocji. Wiedzą o tym badacze bezrobocia od czasów pionierskiej monografii Bezrobotni Marienthalu z 1933 roku (Jahoda, Lazarsfeld, Zeisel 2007) oraz słynnego artykułu z 1935 roku o psychologicznych skutkach bezrobocia autorstwa Bohdana Zawadzkiego i Paula Lazarsfelda (1993).

Socjologia współczesna świadoma jest wagi emocjonalnego wymiaru życia społecznego, sprawa ma zresztą szerszy wymiar: emocje stają się dziś kategorią interdyscyplinarnego dyskursu naukowego. Skupienie się na problematyce emocji nie wyczerpuje oczywiście wielowymiarowej rzeczywistości bezrobocia, ma jednak inny walor: stwarza wyjątkową możliwość bezpośredniego zetknięcia się badacza $z$ badanym trudnym problemem, $w$ tym wypadku $z$ doświadczeniem życia bez pracy.

Waga bezpośredniego kontaktu z badaną rzeczywistością jest niewątpliwą wartością we współczesnej socjologii, w tym w badaniach ubóstwa. W ich dziejach można wyodrębnić wiele kierunków i nurtów badań polegających na dążeniu do maksymalnego zbliżenia między badaczem a badanym; określiłam tę tendencję hasłem „bliżej biednego”, rekonstruując w jej ramach następujące znaczące i wpływowe nurty badań ubóstwa i powiązanych z nim zjawisk: (1) analizy dokumentów osobistych, czyli pamiętników, (2) perspektywa historii mówionej (oral history), czyli gromadzenie bezpośrednich relacji ludzi biednych drogą tzw. wywiadów retrospektywnych, (3) antropologia ubóstwa 
Oscara Lewisa, czyli zwielokrotnione autobiografie ludzi żyjących w ubóstwie, (4) monografie społeczności dotkniętych ubóstwem, (5) aktywizujące badania uczestniczące $z$ udziałem samych zainteresowanych, czyli biednych (Tarkowska 2004). We wszystkich tych nurtach, przybliżających badacza do biednego, ważny był wątek udzielania głosu — dzięki przyjętej metodzie badawczej — osobom tej możliwości pozbawionym, milczącym, „niemym”, w tym ludziom biednym, bezradnym, bezrobotnym. Podkreśla to Anna Zawadzka w swej analizie pamiętników bezrobotnych, dostrzegając w możliwości „mówienia we własnym imieniu” sposób na „odzyskanie godności i uzyskanie podmiotowości społecznej" (Zawadzka 2005, s. 47-48). Kto dziś chce słuchać tego głosu?

Pierwsza wersja niniejszego tekstu, przedstawiona na konferencji w rocznicę powstania Solidarności została nazwana przez jednego z kolegów socjologów „socjologią lamentującą". Zarzucano w dyskusji, że prawda o bezrobotnych jest zupełnie inna, że bezrobotni pracują na czarno lub w ogóle nie chcą pracować, bagatelizowano taki problem, jak myśli i nastroje samobójcze bezrobotnych („lamentem” było cytowanie fragmentów pamiętników dotyczących ich ponurych nastrojów). Nie sposób uogólniać na podstawie jednego epizodu, wydaje się jednak, że świadczy on nie tylko o niewiedzy, ale i o niechęci do poznania trudnych problemów, z którymi zmaga się znaczna część naszego społeczeństwa.

Świat współczesny nie chce słyszeć o biedzie, odgradza się od niej „kordonem sanitarnym obojętności”, jak to obrazowo określił Ryszard Kapuściński (1997, s. 152). Na przepaść między światem bogactwa i światem ubóstwa wskazywał wielokrotnie Zygmunt Bauman (1998, 2004), który pisał o biednych jako ludziach zbędnych w świecie konsumpcji i dostatku, czy Marcin Czerwiński (2000, s. 119), który w ostatniej swej książce pisał o braku „cienia solidarności" między tymi, którym się w nowej rzeczywistości ekonomicznej powiodło, czyli „bohaterami rynku”, a wykluczonymi, ludźmi zbędnymi, stanowiącymi jedynie „koszt” transformacji. Opisał różne kategorie wykluczonych, podkreślał dramatyzm trwałego bezrobocia, stającego się z czasem głównym elementem określającym tożsamość bezrobotnego. „Bezrobotny często poddaje się, staje się coraz bardziej bezrobotny" (Czerwiński 2000, s. 120). Autora szczególnie bolała milcząca zgoda na uznanie bezrobocia za coś najzupełniej zwykłego, za stan niemalże naturalny. Akceptacja bezrobocia i rozmiary wykluczenia obrażają, jego zdaniem, „rozum i serce” i przynoszą wstyd naszej cywilizacji. Nadzieję widział w społecznej nauce Kościoła, ale, jak pisał, „dla tego radykalnego alternatywnego programu, przepełnionego ideą sprawiedliwości społecznej nie widać szans" (Czerwiński 2000, s. 127).

Między „socjologią lamentującą” a socjologią pomijającą i bagatelizującą problemy jest miejsce na inne postawy badacza i inne wersje reprezentowanej przez niego dyscypliny, zwłaszcza gdy rzecz dotyczy doświadczenia ubóstwa i bezrobocia. Po pierwsze, jest miejsce na dążenie do zrozumienia tego doświadczenia, w tym sensie, jaki nadał mu w La misère du monde Pierre Bour- 
dieu (1998, s. 10), zalecając badaczowi: „Ne pas deplorer, ne pas rire, ne pas detester, mais comprendre” - „Nie lamentować, nie wyśmiewać się, nie brzydzić się, lecz zrozumieć" ${ }^{9}$. Zdanie to umieściłam jako motto książki Zrozumieć biednego, ponieważ dążenie do „zrozumienia biednego”, do wypracowania postawy pozwalającej uniknąć skrajności i pułapek sentymentalizmu z jednej strony, a pogardy i kpiny z drugiej, było troską autorek wspomnianej książki. Po drugie, w badaniu tych trudnych zjawisk w mikroskali jednostkowych doświadczeń jest także miejsce na poszerzenie procesu poznania o wymiar emocjonalny i empatię, na „socjologię współodczuwającą” - termin ten odniosłam kilka lat temu do książki Marcina Czerwińskiego Pytając o cywilizacje (Tarkowska 2000). Doświadczenie życia bez pracy, przedstawione w osobistych relacjach bezrobotnych zasługuje na uważną lekturę i zainteresowanie ze strony przedstawicieli różnych odmian socjologii.

\section{BIBLIOGRAFIA}

Bauman Zygmunt, 1998, Zbędni, niechciani, odtraceni — czyli o biednych w zamożnym świecie, „Kultura i Społeczeństwo", nr 2.

Bauman Zygmunt, 2004, Życie na przemiat, tłum. Tomasz Kunz, Wydawnictwo Literackie, Kraków. Balcerzak-Paradowska Bożena i in., 1997, Rodziny wielodzietne w Polsce. Teraźniejszość i przyszłość, IPiSS, Warszawa.

Bourdieu Pierre i in., 1998, La misère du monde, Edition du Seuil, Paris.

CBOS, 2005, Bezrobocie w rodzinach i w doświadczeniu osobistym Polaków, kwiecień.

Czapiński Janusz, Panek Tomasz (red.), 2005, Diagnoza społeczna 2005. Warunki ijakośćżycia Polaków, Wyższa Szkoła Finansów i Zarządzania, Warszawa.

Czerwiński Marcin, 2000, Pytając o cywilizację, WAB, Warszawa.

Dahrendorf Ralf, 1993, Nowoczesny konflikt społeczny. Esej o polityce wolności, tłum. zbiorowe, Czytelnik, Warszawa.

Dahrendorf Ralf, 1999, Czas życia i czas pracy, tłum. Andrzej Pawelec, w: Krzysztof Michalski (red.), Koniec tysiaclecia. O czasie i drogach nowożytności. Rozmowy w Castel Gandolfo, Znak, Kraków.

Drozdowski Rafał, 2002, Rynek pracy w Polsce. Recepcja, oczekiwania, strategie dostosowawcze, Wydawnictwo UAM, Poznań.

Golinowska Stefania, Broda-Wysocki Piotr, 2005, Kategorie ubóstwa i wykluczenia społecznego. Przegląd ujęć, w: Stefania Golinowska, Elżbieta Tarkowska, Irena Topińska (red.), Ubóstwo i wykluczenie społeczne. Badania - metody - wyniki, IPiSS, Warszawa.

GUS, 2004, Warunki życia ludności w 2003 r., Warszawa.

GUS, 2005, Bezrobocie rejestrowane I kwartat 2005 r., Warszawa.

Hrynkiewicz Józefina, 2003, Praca i strach, „Res Publica Nowa”, nr 7.

Jahoda Marie, Lazarsfeld Paul F., Zeisel Hans, 2007, Bezrobotni Marienthalu, tłum. Robert Marszałek, Oficyna Naukowa, Warszawa.

Kapuściński Ryszard, 1997, Lapidarium III, Czytelnik, Warszawa.

Kowalak Tadeusz, 1998, Marginalność $i$ marginalizacja społeczna, Instytut Polityki Społecznej UW, Warszawa.

9 Także Oscar Lewis (1964 s. 8) wskazywał na niebezpieczeństwo z jednej strony „nadmiernego sentymentalizmu", z drugiej — „ujęcia zbyt brutalnego” w badaniu ubóstwa. 
Kutz Kazimierz, 2005, Nie jadę do Gdańska, „Gazeta Wyborcza”, 26 sierpnia.

Lewis Oscar, 1964, Sanchez i jego dzieci. Autobiografia rodziny meksykańskiej, tłum. Aleksandra Frybesowa, PIW, Warszawa.

Narodowa..., 2004, Narodowa Strategia Integracji Społecznej dla Polski, Ministerstwo Polityki Społecznej, Warszawa.

Pamiętniki..., 1967, Pamiętniki bezrobotnych, PWE, Warszawa, 2 t. [reedycja publikacji z 1933 roku: Pamiętniki bezrobotnych. Nr 1-57, Instytut Gospodarstwa Społecznego, Warszawa].

Pamiętniki..., 2005, Pamiętniki bezrobotnych. Materiaty konkursowe, prace nagrodzone, oprac. Andrzej Budzyński, Oficyna Wydawnicza SGH, Warszawa, 4 t.

Psyk-Piotrowska Elżbieta, 1998, Bezrobocie i pauperyzacja środowisk dawnych PGR w Polsce, „Wieś i Rolnictwo", nr 3.

Rifkin Jeremy, 2001, Koniec pracy. Schyłek sity roboczej na świecie i początek ery postrynkowej, Wydawnictwo Dolnośląskie, Wrocław.

Sikorska Małgorzata, 2002, Zmiany postaw Polaków wobec pracy: lęk przed bezrobociem i samorealizacja, w: Aleksandra Jasińska-Kania, Mirosława Marody (red.), Polacy wśród Europejczyków. Wartości społeczeństwa polskiego na tle innych krajów europejskich, Scholar, Warszawa.

Tarkowska Elżbieta, 1998, Ubóstwo w bytych PGR-ach. W poszukiwaniu dawnych źródeł nowej biedy, „Kultura i Społeczeństwo", nr 2.

Tarkowska Elżbieta, 2000a, W stronę socjologii współodczuwającej. Marcina Czerwińskiego „pytania bez odpowiedzi”, „Kultura i Społeczeństwo”, nr 4.

Tarkowska Elżbieta (red.), 2000b, Zrozumieć biednego. O dawnej i obecnej biedzie w Polsce, Typografika, Warszawa.

Tarkowska Elżbieta, 2002, Koniec pegeerowskiego świata $w$ wypowiedziach bytych pracowników PGR-u Owczary, w: Katarzyna Korzeniewska, Elżbieta Tarkowska (red.), Lata ttuste, lata chude... Spojrzenia na biedę $w$ spotecznościach lokalnych, IFiS PAN, Warszawa.

Tarkowska Elżbieta, 2004a, Bliżej biednego — doświadczenia i potrzeby badawcze, „Przegląd Socjologiczny", nr 1 .

Tarkowska Elżbieta, 2004b, Między praca a konsumpcją (z kultura teraźniejszości w tle), w: Marian Kempny, Krzysztof Kiciński, Elżbieta Zakrzewska (red.), Od kontestacji do konsumpcji. Szkice o przeobrażeniach wspótczesnej kultury, ISNS UW, Warszawa.

Tarkowska Elżbieta, 2005, Kategoria wykluczenia społecznego a polskie realia, w: Małgorzata Orłowska (red.), Skazani na wykluczenie, APS, Warszawa.

W trosce..., 2004, W trosce o pracę. Raport o rozwoju społecznym. Polska 2004, UNDP, Warszawa.

Zawadzka Anna, 2005, Bezrobotni z dwudziestolecia międzywojennego i z końca wieku: problemy, postawy, narracje. Analiza „Pamiętników bezrobotnych”, „Kultura i Społeczeństwo”, nr 2.

Zawadzki Bohdan, Lazarsfeld Paul F., 1993, Psychologiczne konsekwencje bezrobocia, tłum. Tadeusz Szawiel, Antoni Sułek, Krzysztof Koseła, „Kultura i Społeczeństwo”, nr 2.

\section{LIFE WITHOUT WORK}

\section{Summary}

The author considers unemployment in Poland in the first years of the twenty-first century as a cause of the growth in poverty and the ensuing social exclusion. These phenomena are connected but not identical. They are also defined differently. In contrast to various conceptions of poverty that seek its causes in the values and behaviors of individuals, the category of social exclusion stresses the social dimension-the impacts of a society that excludes and marginalizes. The author writes about the meaning of 
work in Polish society and gives examples of unemployed people's feelings in connection with not having work, drawn from their own writings. She would like to see these viewpoints taken into consideration in sociological research.

\section{Key words / słowa kluczowe}

unemployment / bezrobocie; poverty / ubóstwo; social exclusion / wykluczenie społeczne; psychological importance of work / psychologiczne znaczenie pracy; diaries or memoirs of the unemployed / pamiętniki bezrobotnych; compassionate sociology / socjologia współodczuwająca 